\title{
Diagnostik Kurikulum Program Studi Destinasi Politeknik Pariwisata Makassar Sebagai Centre Of Excellence Wisata Maritim: Suatu Analisis Networking Process
}

\author{
Muh. Yahya ${ }^{1^{*}}$, Darwis ${ }^{2}$ Agus $^{3}$ \\ ${ }^{123}$ Politeknik Pariwisata Makassar \\ 1Email: yahyaakil@ymail.com, ${ }^{2}$ Email: darwiss40@yahoo.co.id, ${ }^{3}$ Email: agusesmp@gmail.com \\ *Corresponding author
}

\begin{abstract}
This study aims to determine the curriculum applied in running the Tourism Destination Study Program to support the Ministry of Tourism Program which establishes the Tourism Polytechnic as the Center of Excellence for Maritime Tourism. The research method used is descriptive qualitative and quantitative research. There were seven expert informants to determine the criteria and alternative data. Data collected through questionnaires and interviews. Data were analyzed using Analitical Networking Process (ANP) using Super Decision software. The results showed that the results of determining the criteria and alternatives for implementing the curriculum of the Tourism Destination Study Program used a natural, nautical and nautical culture curriculum, with a curriculum base that emphasized more on the technical approach as the basis of the implementation of the vocational curriculum.
\end{abstract}

Keywords: Center of Excellence; Curriculum; Vocational; Tourism

\begin{abstract}
Abstrak. Penelitian ini bertujuan untuk untuk mengetahui kurikulum yang diterapkan dalam menjalankan Program Studi Destinasi Pariwisata untuk mendukung Program Kementerian Pariwisata yang menetapkan Politeknik Pariwisata sebagai Center of Excellence Wisata Maritim. Metode penelitian yang digunakan adalah penelitian deskriptif kualitatif dan kuantitatif. Informan ahli sebanyak tujuh orang untuk menentukan kriteria dan alternative data. Data dikumpulkan melalui angket dan wawancara. Data dianalisis dengan menggunakan Analitical Networking Proces (ANP) dengan menggunakan software Super Decision. Hasil penelitian menunjukkan bahwa hasil penentuan kriteria dan alternatif pelaksanaan kurikulum Program Studi Destinasi Pariwisata menggunakan kurikulum alam bahari, budaya bahari dan bahari buatan, dengan basis kurikulum yang lebih menekankan pada pendekatan teknis sebagai dasar dari pelaksanaan kurikulum vokasional.
\end{abstract}

Kata Kunci: Centre Of Excellece; Kurikulum; Vokasional; Pariwisata

\section{PENDAHULUAN}

Pengelolaan pendidikan tinggi yang berbasis pada kualitas dituntut mempunyai program akademik berbasis kompetensi yang unggul dalam penyiapan skill dan kemampuan akademik berbasis keilimuan. Capaian pembelajaran yang sesuai yang didasarkan pada program akademik yang dijalankan pada suatu institusi pendidikan tinggi, mempengaruhi penyelenggaraan pembelajaran yang berimplikasi pada mutu.

Politeknik sebagai institusi pendidikan tinggi di Indonesia, menyediakan tenaga teknis tingkat menengah dengan berdasarkan jenjang, Diploma Tiga dan Empat, sebagai dasar dalam memadukan konsep dan pandangan ilmu pengetahuan dengan teknologi dengan penerapan teknik-teknik kerja. Capaian pembelajaran pendidikan Diploma Tiga dan Empat pada politeknik harus mampu menerapkan ilmu pengetahuan pada proses dan output dalam bentuk produk .

Fokus utama pendidikan vokasional dalam penyiapan tenaga kerja yang mempunyai skill yang dapat diaplikasikan dalam lingkungan kerja sebagai manusia yang profesiaonal. Penyesuaian dengan sistem adaptasi kebutuhan pada dunia kerja terhadap lulusan, membuat pendidikan vokasional harus lebih fleksibel tentang kebutuhan ilmu dan 
keterampilan, demikain juga dengan tingginya frekuensi perekembangan yang terus dipacu oleh kebutuhan harus mampu disesuaikan oleh pendidikan vokasional.

Strategi Center of Excellence sebagai langkah yang dilakukan Kementeria Pariwisata untuk menetapkan dan memberi tugas dan tanggung jawab kepada keenam Perguruan Tinggi Negeri (PTN Pariwisata) memiliki spesialisasi tertentu pada bidang kajian dan pengembangan pariwisata yang mengacu pada resources dan advantages. Keenam PTNP yang dimaksud adalah: STP Bali diarahkan jadi Center of Excellence Cultural Tourism. STP NHI Bandung jadi Center of Excellence Halal Tourism, Poltekpar Lombok jadi Center of Excellence Culinary Tourism, Poltekpar Makassar Center of Excellence Wisata Maritim, Poltekpar Palembang Center of Excellence Sports Tourism, Poltekpar Medan Center of Excellence Wisata Geopark.

Penyesuain Poltekpar Makassar sebagai Center of Excellence (CoE) Wisata Maritim, oleh pemerintah dalam hal ini Kementerian Pariwiasata, diharapkan mampu memberikan jawaban atas tantangan yang diberikan untuk fokus pada kajian bahari, pengembangan produk wisata bahari, pelibatan mahasiswa pada program-program wisata bahari. Elemen yang diharapkan memberi sumbangsih yang cukup besar adalah program studi yang ada pada Poltekpar Makassar. Dengan menetapkan salah satu program studi yang ada di kampus tersebut sebagai pusat kajian yang didukung dengan program-program akademiknya. Salah satu program studi yang diharapkan tersebut adalah Program Studi Manajemen Kepariwisataan yang akan berubah nama menjadi Program Studi Destinasi Pariwisata, dimana Program studi tersebut adalah Program studi yang mengembangkan keilmuan vokasional yang berbasis sistem pengelolaan kepariwisataan yang didalamnya mengarah pada manajemen pengelolaan destinasi pariwisata

Dari berbagai jenis penyelenggaran pendidikan dengan status politeknik, bidang kapriwisataan membutuhkan pengembangan sumberdaya manusia melalui jalur pendidikan, sehingga terbentuk politeknik pariwisata. Sebagai perwujudan pemerataan pendidikan kepariwisataan di seluruh Indonsesia, Politeknik Pariwisata Makassar yang berada di Kota Makassar merupakan interpretasi pemenuhan kebutuhan pendidikan kepariwisataan di Kawasan Timur Indonesai, yang juga diikuti perkembangan kepariwisataan di Kota Makassar dan sekitarnya, dengan terus bertambahnya jumlah hotel, restoran, daya tarik wisata dan sarana wisata lainnya Provinsi Sulawesi Selatan yang memliki bentang alam dengan karakteristik tersendiri, menjadi suatu kekuatan dan peluang yang perlu untuk digarap dengan profesional, sehingga menghasilkan produk destinasi atau daya tarik wisata yang unggul, yang diharapkan menjadi kekuatan dan peluang yang besar dalam pengmbangan potensi wisata bahari. Untuk mendukung pengembangan tersebut, maka dibutuhkan pengembangan sumber daya manusia melalui jalur pendidikan vokasional pada perguruan tinggi pariwisata yang spesifik pada bidang ilmu wisata bahari, dengan dukungan kurikulum yang sesuai kebutuhan pada bidang ilmu tersebut.

Perkembangan Politeknik Pariwisata Makassar yang terus terjadi sejak berdiri sampai sekarang dengan mengalami tiga kali perubahan status, membuat sistem pengelolaan menjadi lebih baik. Pengembangan kapasitas sumberdaya manusia dalam sistem dan manajemen pengelolaan pendidikan terus dilakukan oleh manajemen, untuk menunjang kebutuhan kualitas pengeleloaan institusi yang lebih baik. Jurusan dan progrm studi yang ada sebagai perwujudan kebutuhan industri, dengan menyelenggarakan pendidikan kedalam dua pola yaitu, teori dan praktek.

Nygaard dkk, (2008).Kompetensi lulusan adalah kemampuan untuk menerapkan pengetahuan dan keterampilan sehingga tugas yang menjadi tanggung jawabnya dapat ditangani dan diselesaikan sesuai dengan cara yang memenuhi standar kinerja yang diinginkan dalam masing-masing konteks dan seseorang dipandang sebagai pelaku yang sesuai akan dianggap kompeten.

Sebagai salah satu program studi yang diharapakan mampu memberikan kompetensi bidang kepariwisataan, Program studi Destinasi Pariwisata harus mempunyai kurikulum yang berbasis pengelolaan kepariwisataan yang lebih spesifik pada kompetensi skill dan keilmuan daya tarik wisata. Kurikulum yang telah dijalankan sekarang pada prinsipnya telah memenuhi standar kompetensi kebutuhan skill lulusan yang akan diaplikasikan pada usaha daya tarik wisata. Namun masih perlu dilakukan kajian tentang keterkaitan kebutuhan skill dan ilmu yang dibutuhkan usaha penyedia daya tarik wisata yang sifatnya research lebih 
mendalam, untuk memastikan kurikulum yang dijalankan dalam proses perkuliahan sejalan dengan kebutuhan usaha daya tarik wisata.

Keterkaitan antara kurikulum dengan pertumbuhan usaha daya tarik wisata yang berbasis alam, budaya, buatan dan bahkan perpaduan antara ketiganya pada saat sekarang ini terus berkembang. Penyebaran daya tarik wisata di daerah-daerah yang ada di Sulawesi Selatan secara massif terjadi, baik yang dikelola pihak pemerintah maupun sewasta. Dukungan tenaga kerja trampil dan kemampuan manajerial dalam menangani usaha daya Tarik, akan memberikan solusi yang tepat dalam sistem pengelolaan yang baik, sehingga akan memberikan dampak pada peningkatan kualitas produk usaha daya tarik wisata, yang dimulai dari sistem atau pola perencanaan yang baik sampai pada pola pengelolaan yang profesional. Indikasi dilapangan menunjukkan bahwa hampir secara keseluruhan usaha daya tarik yang tersebar disetiap wilayah kabupaten/kota di Sulawesi Selatan belum sepenuhnya dikelola dengan baik, yang berdampak pada kualitas porduk usaha daya Tarik itu sendiri. Hal ini diakibatkan pemenuhan sumber daya manusia profesioal bidang daya tarik belum mampu terealisasi. Jumlah daya tarik dengan ketersediaan jumlah sumberdaya manusia tidak seimbang, sehingga pemenuhan kebutuhan tenaga terampil dibidang ini tidak terealisasi dengan baik. Dengan demikian diperlukan suatu rancangan kurikulum yang mampu merepresntasikan program pemerintah yang menetapkan Politeknik Pariwisata Makassar sebagai Centre Of Excellence Wisata Maritim dalam menunjang pengembangan pariwisata di Sulawesi Selatan sebagai kekuatan wisata bahari di Indonesia.

Untuk memastikan kurikulum yang dijalankan pada Program studi Destinasi Pariwisata mempunyai keterkaitan antar pengembangan kompetensi lulusan yang akan diterapkan pada usaha daya tarik wisata, maka berdasarkan masalah tersebut, kajian dalam penelitian ini mengangkat tema Diagnostik Kurikulum Program Studi Destinasi Poltekpar Makassar Sebagai Centre Of Excellence "Wisata Maritim" Dengan Analitical Networking Process (ANP).

Latar belakang penilitian diatas menggambarkan sesuatu hal yang perlu untuk dikaji berkaitan dengan kurukulum yang dijalankan kaitanya dengan kualitas lulusan yang dihasilkan (kompetensi), apakah kurikulum tersebut dapat memenuhi kebutuhan skill dalam pengelolaan usaha daya tarik wisata. Sehingga rumusan masalah pada penelitian ini yaitu: Menentukan basis kurikulum dalam menjalankan Program Studi Destinasi Pariwisata untuk mendukung Program Kementerian Pariwisata yang menetapkan Politeknik Pariwisata sebagai Center of Excellence Wisata Maritim Tujuan yang akan dicapai dalam penelitian yaitu untuk mengetahui Kurikulum yang akan diterapkan dalam menjalankan Program Studi Destinasi Pariwisata untuk mendukung Program Kementerian Pariwisata yang menetapkan Politeknik Pariwisata sebagai Center of Excellence Wisata Maritim.

Nurhidayat dan Sadari (2018)

Kurikulum Integratif Dan Pengaruhnya Terhadap Kompetensi Lulusan (Studi Pada Fakultas Ekonomi International Islamic University Malaysia). With the integrative curriculum developed by the International Islamic University Malaysia Faculty of Economics, it produces graduates who are professional, knowledgeable who are inspired by Islamic values and ethics that will develop Muslims and achieve progress in harmony with the ideals of Islam. Dengan kurikulum integratif yang dikembangkan oleh Fakultas Ekonomi Internasional, Fakultas Ekonomi Universitas Malaysia, menghasilkan lulusan yang profesional, berpengetahuan luas yang terinspirasi oleh nilai-nilai dan etika Islam yang akan mengembangkan umat Islam dan mencapai kemajuan yang selaras dengan citacita Islam.

Ahmad Rifandi (2013) The Quality Of Instruction And Graduate Competence Of Diploma III Polytechnic. The findings showed that the learning quality in POLBAN was influenced by teacher professionalism and facilities, whereas the learning quality in POLMAN was influenced by media and facilities.

Moch Bruri Triyono, (2017). Perubahan kebutuhan tenaga kerja saat ini dan masa depan sudah mulai terlihat perubahannya akibat revolusi industri ke empat (i4.0). Revolusi industri ke 4 mempunyai ciri teknologi yang menyatu dengan masyarakat dan tubuh manusia, robotik, quantum komputasi, bioteknologi, 3D printing, otomasi kendaran, internet, sistem virtual dan fisik bekerjasama yang secara global.

Lan Jiang, George Alexiakis, (2017). 
That managers and students have different perceptions regarding entry-level managerial competencies. Perhatian pendidikan terhadap relevansi lulusan dengan industri ditambah dengan penekanan pada program peningkatan hasil pendidikan. Studi ini menentukan pengetahuan dan keterampilan yang paling dibutuhkan para pengusaha ketika mempekerjakan manajer tingkat pemula dalam ilmu manajemen bisnis perhotelan.

Namhyun Kim, Joungkoo Park, JeongJa Choi. (2017). Perceptual Differences In Core Competencies Between Tourism Industry Practitioners And Students Using Analytic Hierarchy Process (AHP)". The results show that both groups emphasize core competencies in common, including a considerate attitude, communication ability, integrated thinking ability, language ability, and a goal-orientated disposition. However, there are different perceptions regarding the relative importance among competencies. The results reflect insights into the amount of consideration that needs to be given to bolster competency-based tourism education in an effort to prepare students in developing both job-specific and generic skills. Hasilnya mencerminkan bahwa beberapa pertimbangan yang perlu dilakuakn untuk meningkatkan pendidikan pariwisata berbasis kompetensi dalam upaya untuk mempersiapkan siswa dalam mengembangkan keterampilan.

Muhammad Yusuf, D. Ari. A Samsura, Pujo Semedi Hargo Yuwono (2018). "Toward a framework for an undergraduate academic tourism curriculum in Indonesian Universities: Some perspectives from stakeholders". undergraduate academic tourism curriculum, namely: The Government which develops the We analyse policy documents as well opinions of stakeholders contributing to the development of the general framework for curriculum development in Indonesian universities; nongovernmental tourism associations which assist universities with opinions and guidance; tourism academics who develop and implement the curriculum in the classroom; and tourism trade associations. Two issues characterize the development of the tourism curriculum namely: determining the appropriate balance between vocational and academic frameworks, and an aspiration to move from inter- to monodisciplinary instruction.

Fitroh, strategi pembelajaran pada perguruan tinggi khususnya Program Studi
Sistem Informasi harus diberi fondasi terlebih dahulu dengan internalisasi sosiologi kritis, inovasi, kreativitas, dan mentalitas. Hal ini tidak berhenti pada fondasi saja, tetapi juga diupayakan merasuki kurikulum yang ada pada perguruan tinggi. Selain itu, juga mengubah strategi pembelajaran yang selama ini berdasarkan pada konsep reproductive view of learning menjadi constructive view of learning.

\section{METODE PENELITIAN}

Penelitian ini merupakan penelitian deskriptif kualitatif untuk mengetahui pandangan oleh para pakar, praktisi, dan akademisi dan pelaku industri pariwisata berkaitan dengan kurikulum yang relefan diterapakan di Program Studi Destinasi Pariwisata. Pemilihan informan dalam penelitian ini mempertimbangkan pemahaman informan terhadap fokus kajian substansi kurikulum dan kemaritiman di Indonesia. Jumlah informan ahli atau kunci dalam penelitian ini adalah 7 orang informan, dengan pertimbangan bahwa informan tersebut dianggap kompoten dan dapat memberikan pendapat secara mendalam pada fokus kajian dalam penelitian ini. Ketentuan dalam penggunaan Analitical Networking Process (ANP). Tahapan-tahapan dalam pengolahan data dengan menggunakan ANP yaitu penentuan kriteria, pembuatan konstruksi model, kuantifikasi model, sintesis dan analisis hasil.

\section{HASIL DAN PEMBAHASAN}

Peninjauan dan penilaian pada pelaksanaan pendidikan yang telah dijalankan oleh Program Studi Manajemen Kepariwisataan, Politeknik Pariwisata Makassar (Poltekpar Makassar) sebagai langkah dalam memberikan evaluasi pada tata kelola Program Studi yang telah dijalankan selama ini. Hal ini dimaksudkan untuk melihat apakah kurikulum yang telah dijalankan berdasarkan atas kebutuhan skill pada usaha daya tarik wisata, sehingga pemenuhan skill dalam pengelolaan daya tarik wisata dapat didukung oleh Program Studi Manajemen Kepariwisataan. Dengan alasan tersebut, Program studi ini akan berubah menjadi Program Studi Destinasi Pariwisata.

Poltekpar Makassar sebagai Center of Excellence Bahari perlu mendapat dukungan dari salah satu program studi yang mempunyai basis keilmuan pada kajian bahari, pengembangan produk wisata bahari, pelibatan 
mahasiswa pada program-program wisata bahari. Dimana dalam program yang dijalankan oleh program studi tersebut, merupakan program yang perlu dukungan dari semua elemen Poltekpar Makassar. Elemen yang diharapkan memberi sumbangsih yang cukup besar adalah program studi yang ada pada Poltekpar Makassar. Salah satu program studi yang diharapkan tersebut adalah Program studi Destinasi Pariwisata, dimana Program studi tersebut adalah program studi yang mengembangkan keilmuan vokasional yang berbasis sistem pengelolaan kepariwisataan yang didalamnya mengarah pada manajemen pengelolaan destinasi pariwisata.

Mengacu pada kurikulum yang telah dijalankan selama ini, maka apabila ingin dikaitkan dengan program Kementerian Pariwisata yang berkaitan dengan Poltekpar Makassar sebagai Center of Excelence Bahari, dianggap perlu penyesuaian kurikulum dengan mengarahkan pada kurikulum bahari. Maka dalam kajian pada penelitian ini, peneliti merumuskan alternatif kurikulum yang diarahkan pada kurikulum berbasis bahari.

Dalam penelitian ini dilakukan beberapa langkah sebelum menentukan alternatif pilihan kurikulum sebagai fokus kurikulum yang akan diusulkan. Langkahlanglah dalam penentuan alternatif sebagai berikut:

\section{Menentukan Kriteria dan Alternatif}

Dalam teknik penentuan kriteriakriteria peneliti memberikan beberapa solusi yang akan dipilih oleh narasumber ahli, kemudian narasumber tersebut memberikan peniliaan dan perengkingan berdasarkan tingkatan kepentingan dari alternatif node yang telah dirumuskan oleh peneliti. Hasil penentuan peringkat kriteria yang telah dipilih oleh narasumber ahli yaitu; (1) budaya bahari, (2) alam bahari, dan (3) bahari buatan.

Langkah selanjutnya merumuskan node yang akan digunakan dalam menentukan alternatif, dengan menghasilkan node dalam alternatif. Hasil dari pemilihan node dalam alternatif yang telah dipilih oleh nara sumber ahli berdasarkan peringkat kepentingan yaitu; (1) berbasis manajemen dan teknis, (2) berbasis manajemen, dan (3) berbasis teknis.

\section{Konstruksi Model}

Kriteria-kriteria dan alternatif alternatif yang telah dirumuskan berdasarkan masukan oleh para responden ahli dalam pengambilan keputusan pada kurikulum yang dapat digunakan dalam pelaksanaan Program Studi Destinasi. Gambar berikut menunjukkan motode ANP dalam pengolahan data penelitian dengan mengunakan Super Decisions.

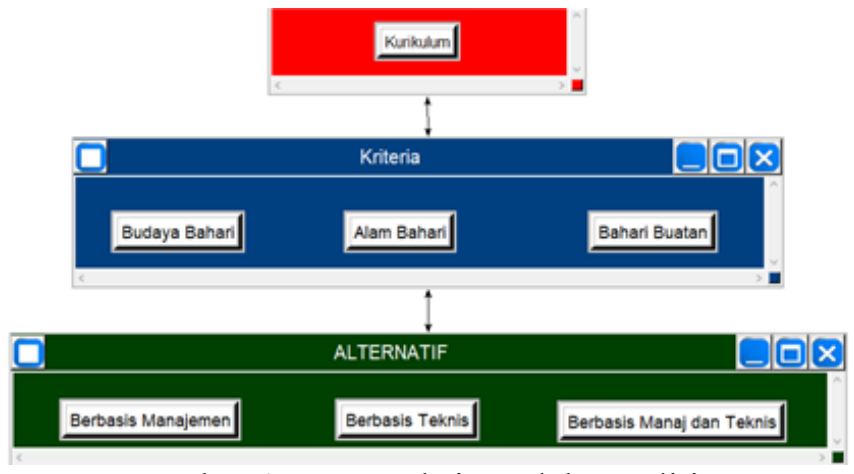

Gambar 1. Konstruksi Model Penelitian

Pada gambar diatas menunjukkan hubungan/simpul timbal balik yang dihasilkan oleh metode ANP, dimana cluster-cluster yang ada pada konstruksi model yang dibangun menunjukkan hubungan. Hubungan yang ditunjukkan bukan hanya satu arah, akan tetapi hubungan yang terbentuk membentuk hubungan/simpul timbal balik. Cluster-cluster dapat terikat/tergantung pada node dan dapat juga terikat/tergantung pada sesama cluster. Selanjutnya, node-node itu sendiri dapat tergantung pada cluster-cluster dan pada sesama node.
Pada analisis ANP diatas dapat dilihat hubungan yang terbentuk antara cluster yang satu dengan cluster yang lain yang biasa disebut dengan outer dependence. Seperti yang dapat dilihat pada gambar diatas, cluster Goal mempunyai hubungan langsung dengan cluster criteria maupun dengan cluster alternatif. Sementara terdapat hubungan/simpul dalam cluster criteria dengan node yang ada didalamnya, sehingga cluster ini terhubung dengan dirinya sendiri dan membentuk hubungan loop yang disebut inner dependence.

Masing-masing node pada cluster-cluster 
tersebut yaitu, pada cluster Goal terdapat node kurikulum, cluster kriteria terdiri node dari budaya bahari, alam bahari dan bahari buatan, sedangkan cluster kriteria terdiri dari node berbasis manajemen, berbasis teknis, berbasis manajemen dan teknis.

\section{Kuantifikasi Model}

a. Kuantifikasi Kurikulum. Komparasi dalam menentukan kurikulum dengan cluster kriteria kurikulum, dengan menggunakan node budaya bahari, alam bahari, dan bahari buatan. Nilai prioritas yang dihasilkan sesuai data pada pengisian kuesioner dengan menggunakan super decisions dan menghasilkan results yaitu alam bahari sebesar 0,36 , bahari buatan 0,28 dan budaya bahari 0,35 .

b. Kuantifikasi Budaya Bahari. Komparasi dalam menentukan kurikulum dengan cluster kriteria budaya bahari, dengan menggunakan node manajemen, teknis, dan manajemen dan teknis. Nilai prioritas yang dihasilkan sesuai data pada pengisian kuesioner dengan menggunakan super decisions dan menghasilkan results yaitu manajemen dan teknis sebesar 0,22, manajemen 0,57 dan teknis 0,72.

c. Kuantifikasi Alam Bahari. Komparasi dalam menentukan kurikulum dengan cluster kriteria alam bahari, dengan menggunakan node manajemen, teknis, dan manajemen dan teknis. Nilai prioritas yang dihasilkan sesuai data pada pengisian kuesioner dengan menggunakan super decisions dan menghasilkan results yaitu manajemen dan teknis sebesar 0,22, manajemen 0,57 dan teknis 0,72.

d. Kuatifikasi Bahari Buatan. Komparasi dalam menentukan kurikulum dengan cluster kriteria bahari buatan, dengan menggunakan node manajemen, teknis, dan manajemen dan teknis. Nilai prioritas yang dihasilkan sesuai data pada pengisian kuesioner dengan menggunakan super decisions dan menghasilkan results yaitu manajemen dan teknis sebesar 0,22, manajemen 0,57 dan teknis 0,72.

e. Kuantifikasi Manajemen. Komparasi dalam menentukan kurikulum dengan cluster alternatif manajemen, dengan menggunakan node budaya bahari, alam bahari, dan bahari buatan. Nilai prioritas yang dihasilkan sesuai data pada pengisian kuesioner dengan menggunakan super decisions dan menghasilkan results yaitu alam bahari 0,48 , bahari buatan 0,76 dan budaya bahari 0,19 .

f. Kuantifikasi Teknis. Komparasi dalam menentukan kurikulum dengan cluster alternatif teknis, dengan menggunakan node budaya bahari, alam bahari, dan bahari buatan. Nilai prioritas yang dihasilkan sesuai data pada pengisian kuesioner dengan menggunakan super decisions dan menghasilkan results yaitu alam bahari 0,76 , bahari buatan 0,19 dan budaya bahari 0,05 .

g. Kuantifikasi Manajemen dan Teknis. Komparasi dalam menentukan kurikulum dengan cluster alternatif manajemen dan teknis, dengan menggunakan node budaya bahari, alam bahari, dan bahari buatan. Nilai prioritas yang dihasilkan sesuai data pada pengisian kuesioner dengan menggunakan super decisions dan menghasilkan results yaitu alam bahari 0,33 , bahari buatan 0,33 dan budaya bahari 0,33 .

\section{Sintesis Hasil Penelitian}

Hasil ANP dengan menggunakan super decisions didapatkan:

\begin{tabular}{|c|c|c|c|c|}
\hline \multicolumn{5}{|c|}{ Here are the priorities. } \\
\hline Icon & Name & & alized by Cluste & Limiting \\
\hline No Icon & Manaj dan Teknis & Г & 0.21932 & 0.054830 \\
\hline Nolcon & Manajemen & Г & 0.05687 & 0.014218 \\
\hline No Icon & Teknis & 「 & 0.72381 & 0.180951 \\
\hline No Icon & Kurikulum & I & 1.00000 & 0.250000 \\
\hline Nolcon & Alam Bahari & I & 0.49665 & 0.248326 \\
\hline Nolcon & Bahari Buatan & I & 0.28619 & 0.143097 \\
\hline No Icon & Budaya Bahari & [ & 0.21715 & 0.108577 \\
\hline
\end{tabular}

Gambar 2. Hasil Olah Data Prioritas Pemilihan Kurikulum

Pada Cluster Kriteria dan Cluster Alternatif Cluster Kriteria Pemilihan Kurikulum.

Node yang terdiri dari: budaya bahari, Alam
Bahari, dan Bahari Buatan. Hasil peringkat prioritas yang mendapatkan nilai bobot prioritas terbesar yaitu alam bahari dengan nilai bobot 
prioritas terbesar sebesar 0,50 , selanjutnya secara berurutan peringkat prioritas terbesar selanjutnya yaitu bahari buatan dengan nilai bobot prioritas sebesar 0,29 dan peringkat prioritas selanjunya yaitu budaya bahari dengan peringkat prioritas sebesar 0,22 .

Cluster Alternatif Pemilihan

Kurikulum. Node yang terdiri dari: Kurikulum berbasis manajemena, kurikulum berbasis teknis, dan kurikulum yang berbasisi perpaduan antara manajemen dan teknis. Hasil peringkat prioritas yang mendapatkan nilai bobot prioritas terbesar yaitu teknis dengan nilai bobot prioritas terbesar sebesar 0,72 , selanjutnya secara berurutan peringkat prioritas terbesar selanjutnya yaitu manajemen dan teknis dengan nilai bobot prioritas sebesar 0,22 dan peringkat prioritas selanjunya yaitu manajemen dengan peringkat priorotas sebesar 0,06 .

Dukungan program pelaksanaan pendidikan politeknik pariwisata yang berbasis pada vokasional akan mengarahkan semua program studi melakukan penyesuaian terhadap pelaksanaan pengelolaan pada program studi itu sendiri. Fokus utama dalam pengelolaan program studi, untuk memberikan warna atau penciri tersendiri sesuai program bidang vokasional yang dijalankan.

Berdasarkan aturan tentang pengelolaan perguruan tinggi di Indonesia, maka sesuai Keputusan Menteri Riset, Teknologi, dan Pendidikan Tinggi Republik Indonesia Nomor 257/M.KPT/2017, Tentang Nama Program Studi Pada Perguruan Tinggi, Program Vokasi Diploma III dan Sarjana Terapan. Seiring dengan perubahan nomenklatur dari Direktorat Jenderal Pendidikan Tinggi, Kementerian Riset dan Pendidikan Tinggi, dilakukan perubahan atau penysuaian nama Program Studi Manajemen Kepariwisataan menjadi Program Studi Destinasi Pariwisata. Penyesuaian nomenklatur Program Studi Manajemen Kepariwisataan menjadi Program Studi Destinasi Pariwisata memberikan implikasi terhadap pengelolaan dan sistem pelakasanaan kurikulum pada program studi yang baru yaitu Destinasi Pariwisata. Implikasi yang akan terjadi berpengaruh pada sistem manajerial program studi, kurikulum dan program-program pengaplikasian mahasiswa pada masyarakat .

Perubahan yang sangat mendasar dan yang akan menentukan keberhasilan dalam menjalankan program-program yang ada pada Program Studi Destinasi Pariwisata adalah dari sisi manajerial. Manajemen pelaksanaan mulai dari penyesuaian adminstrasi kemahasisiwa, adminsitrasi kurikulum, administrasi penugasan sumber daya manusia (staf fungsional maupun non fungsional), program pembelajaran teori dan praktek, program praktek-praktek kerjasam dengan industri atau stakeholder, program penelitian, program pengabdian pada masyarakat, seluruh program yang akan diajalankan harus mengacu pada basis kurikulum destinasi.

Jika dilakukan pengklasifikasian berdasarkan kurikulum destinasi, maka jenis kurikulum destinasi yang ada berdasarkan kriteria yang telah dihasilkan dalam penelitian ini yaitu, destinasi wisata alam, destinasi wisata budaya, destinasi wisata buatan akan menjadi dasar dan arah capaian pengelolaan Program studi yang akan dilakukan oleh manajemen pada tingkat Program studi yang akan mengarahkan kebutuhan kurikulum berdasarkan kebutuhan pemenuhan kebutuhan skill lulusan.

Ketiga model pengembangan kurikulum tersebut merupakan dasar pelaksanaan pengelolaan Program Studi Destinasi Pariwisata untuk fokus mendukung program centre of exelence wisata maritim yang merupakan potensi terbesar yang dimiliki yang berada di wilayah bagian timur dengan mengedepankan ilmu sebagai dasar dalam mendapatkan kemampuan manajerial dan kemampuan skill pada mahasiswa. Pengembangan konsep, model, sistem, strategi pengelolaan dan teknikteknik yang harus dilakukan dalam pengelolaan wisata alam bahari sebagai dasar pengembangan skill pada mahasisiwa melalui kurikulum yang di bentuk dan yang akan dijalankan.

Model kurikulum yang seharusnya dikembangkan dan diterapkan adalah kurikulum yang mempunyai landasan yang kuat yang mengarahkan pada kemampuan skill mahasiswa untuk mendukung penyiapan tenaga-tenaga terampil yang sifatnya integratif dalam bidang dan jenis destinasi tersebut. Hal tersebut sejalan dengan hasil penelitian yang dilakukan oleh Nurhidayat dan Sadari (2018), With the integrative curriculum developed by the International Islamic University Malaysia Faculty of Economics, it produces graduates who are professional, knowledgeable who are inspired by Islamic values and ethics that will develop Muslims and achieve progress in harmony with the ideals of Islam. Penelitian dengan menggunakan uji regresi tersebut menggambarkan kurikulum integratif yang 
dikembangkan oleh Fakultas Ekonomi Internasional, Fakultas Ekonomi Universitas Malaysia, menghasilkan lulusan yang profesional, berpengetahuan luas yang terinspirasi oleh nilai-nilai dan etika Islam yang akan mengembangkan umat Islam dan mencapai kemajuan yang selaras dengan citacita Islam. Jika diinterpretasikan arti dari lulusan yang professional dan berpengatuhuan luas dari penelitian tersebut, maka maksud yang diharapakan dalam pengembangan kurikulum yang berbasis wisata maritim dalam penelitian ini adalah kemampuan profesionalitas lulusan Program Studi Destinasi dalam mengintegrasikan skill pada daya tarik wisata, yang tebentuk dari rancangan kurikulum yang ada. Sehingga mampu mendukung kemampuan lulusan dalam pengelolaan daya tarik wisata yang ada disulawesi selatan.

Namhyun Kim, Joungkoo Park, JeongJa Choi. (2017). Perceptual Differences In Core Competencies Between Tourism Industry Practitioners And Students Using Analytic Hierarchy Process (AHP)". The results show that both groups emphasize core competencies in common, including a considerate attitude, communication ability, integrated thinking ability, language ability, and a goal-orientated disposition. However, there are different perceptions regarding the relative importance among competencies. The results reflect insights into the amount of consideration that needs to be given to bolster competency-based tourism education in an effort to prepare students in developing both job-specific and generic skills. Hasil penelitian menunjukkan penekanan pada kompetensi inti, mencerminkan peningkatan pendidikan pariwisata berbasis kompetensi dalam upaya untuk mempersiapkan siswa dalam mengembangkan keterampilan khusus pada pekerjaan. Penelitian tersebut memberikan gambaran bagaimana kebutuhan teknis yang harus dimiliki oleh tenaga kerja pariwisata mutlak dibutuhkan. Sehingga jika dihubungkan dengan penelitian ini sejalan dengan hasil temuan pada peringkat prioritas dari hasil analisi ANP, yang menunjukkan bahwa nilai bobot prioritas terbesar yaitu teknis dengan nilai sebesar 0,72381. Kemampuan teknik yang dimaksud dalam penelitian ini yaitu, bekal skill berdasarkan kompetensi operasional daya tarik wisata yang harus dimiliki oleh lulusan. Skill tersebut harus didapatkaa dari pelaksanaan pendidikan pada Program Studi Destinasi Pariwisata dari kurikulum yang dijalankan.

Muhammad Yusuf, dkk (2018). Dalam penelitiannya yang berjudul "Toward a framework for an undergraduate academic tourism curriculum in Indonesian Universities: Some perspectives from stakeholders." Penelitian tersebut mengungkap ada dua aspek yang mencirikan pengembangan kurikulum pariwisata yaitu, keseimbangan antara vokasional dan sistim akademis. Jika penelitian tersebut dikaitkan dengan penelitian ini, maka dapat dilihat persamaan dari aspek kajian yang terkait dengan system pengelolaan pendidikan vokasional, dimana kurikulum yang dijalankan lebih menekankan pada aspek teknis yaitu penguasaan keterampilan berdasarkan kompetensi kerja, dimana didalamnya harus mengintegrasikan kemampuan akademis yang bersifat managerial. Kondisi yang terjadi dalam pengelolaan daya tarik wisata, tidak hanya pelaksanaan kerja pada tenaga kerja yang terlibat didalmnya harus didukung oleh kemampuan teknis, tetapi juga dibutuhkan kemampuan menejerial. Kemampuan teknis untuk mendukung operasional dalam hal pelayanan, sedangkan kemampuan menejerial adalah untuk mendukung system pengelolaan daya tarik pada aspek manajemen.

Paul R. Fidgeon, (2010). Dalam penelitian Tourism education and curriculum design: A time for consolidation and review. Analysis of curriculum models, the importance of developing academic vocational and key transferable skills and the need to add value and increase employability. Pentingnya mengembangkan pendidikan kejuruan dan keterampilan, dimana skill yang didapatkan dapat diterapkan dalam meningkatkan kemampuan kerja, sejalan dengan hasil penelitian ini, diamana menghasilkan rumusan kurikulum Program Studi Destinasi Pariwisata yang natinya akan dijalankan, diharapakan mampu memberikan bekal skill pada pengelolaan daya tarik wisata bahari. Kemampuan skill dari hasil penelitian ini yaitu berbasis teknis dan manajemen.

Selanjutnya setelah didukung dengan kurikulum yang baik, untuk mendukung pengaplikasian kurikulum tersebut, maka dibutuhkan program-program yang disediakan oleh pengelola program studi untuk memfasilitasi mahasiswa menerapkan ilmu yang diperoleh dari kampus pada pelaksanaan di dunia kerja. Sistem pengaplikasian ini dengan program pemagangan mahasiswa pada 
tingkat semester yang lebih tinggi dengan melakukan kerjasama dengan pihak industri/usaha daya tarik wisata tentang sistem pengelolaan yang dilakukan pada industri/usaha tersebut. Program dukungan lain dalam bentuk praktek adalah Praktek Lapangan Pariwisata, dimana pelaksanaanya mengacu pada penerapan ilmu di lapangan dengan langsung ke masyarakat dengan melakukan kajian-kajian pariwista yang langsung menginventarisir, mengidentifikasi, memecahkan masalah, dan memberikan solusi dalam memberikan program-program peningkatan kesejahteraan masyarakat dalam bidang pariwisata dan memberikan solusi dari persepektif ilmu pariwisata.

Untuk itu diharapkan kehadiran Program studi Destiansi Pariwisata dalam mendukung program Kemementerian Pariwisata dengan menetapkan Poltekpar Makassar Sebagai Centre of Excellence wisata maritim, untuk terus mengembangkan kurikulum berdasarkan kebutuhan pengelolan daya tari wisata yang ada di Kawasan Timur Indonesia khsunya di wilayah Sulawesi Selatan yang lebih didominasi wilayah maritime, dengan menyesuaikan sistem yang telah berkembangan dimasyarakat pariwisata dengan memunculkan inovasi-inovasi baru pada bidang pariwisata melalui program-program kurikulum destinasi pariwisata yang kompetitif.

\section{KESIMPULAN DAN SARAN}

Hasil analisis Analitical Networking Process menunjukkan peringkat prioritas yang mendapatkan nilai bobot prioritas pertama yaitu teknis, dengan nilai bobot prioritas terbesar sebesar 0,72381 , selanjutnya peringkat prioritas kedua yaitu manajemen dan teknis, dengan nilai bobot prioritas sebesar 0,21932 dan peringkat prioritas ketiga yaitu manajemen, dengan peringkat prioritas sebesar 0,05687 . Perubahan nama program studi tersebut, memberikan implikasi terhadap pengelolaan dan sistem pelakasanaan kurikulum pada program studi yang baru yaitu Destinasi Pariwisata. Implikasi yang akan terjadi berpengaruh pada sistem manajerial program studi, kurikulum dan program-program pengaplikasian mahasiswa pada masyarakat. Jika hasil tersebut diimplementasikan pada kurikulum, dengan fokus utama pada bidang bahari, maka untuk mendukung kebijakan Kementerian Pariwisata menetapkan Poltekpar Makassar seabagai center of excellence wisata maritim, lebih fokus pada kurikulum dengan dasar kemampuan pengelolaan dan skill destinasi wisata alam, wisata budaya, dan buatan wisata buatan. Sedangkan basis pengelolaan kurikulum diarahkan pada kurikulum yang bersifat teknis dan manajemen.

\section{DAFTAR RUJUKAN}

Fitroh, 2011. Pengembangan Kurikulum Berbasis Kompetensi dan Strategi Pencapaian. Jurnal Sistem Informasi, 4(2),

Jiang, Lan., Alexiakis, George., 2017. Comparing Students' And Managers' Perceptions Of Essential Entry-Level Management Competencies In The Hospitality Industry: An Empirical Study. Journal Of Hospitality, Leisure, Sport \& Tourism Education. Volume 20. Https://Www.Sciencedirect.Com/Science /Article/Pii/S1473837616300387

Namhyun Kim, Joungkoo Park, Jeong-Ja Choi. 2017. Perceptual Differences In Core Competencies Between Tourism Industry Practitioners And Students Using Analytic Hierarchy Process (Ahp). Journal Of Hospitality, Leisure, Sport \& Tourism Education. Volume 20. Https://Www.Sciencedirect.Com/Science /Article/Pii/S1473837617300709.

Nurhidayat, Sadari, Tambun. Inisa. 2018. Kurikulum Integratif Dan Pengaruhnya Terhadap Kompetensi Lulusan : Studi Pada Fakultas Ekonomi International Islamic University Malaysia Learning Community. Jurnal Pendidikan Luar Sekolah. Vol 2 No 2. Http://Garuda.Ristekdikti.Go.Id/Journal/ Article/487284

Paul R, Fidgeon. 2010. Tourism Education and Curriculum Design: A Time For Consolidation And Review. Journal of Hospitality and Tourism Management. Volume 30, March 2017, Pages 65-72

Sudrajat, A. 2009. Prinsip Pengembangan Kurikulum (online). (http://akhmadsudrajat.wordpress.com, diakses 26 Desember 2009).

Triyono, M, Bruri. 2017. Tantangan Revolusi Industri Ke 4 (I4.0) Bagi Pendidikan Vokasi. Seminar Nasional Vokasi Dan Teknologi (Semnasvoktek). DenpasarBali, 
Yusuf, Muhammad. 2018. Toward A Framework For An Undergraduate Academic Tourism Curriculum In Indonesian Universities: Some Perspectives From Stakeholders. Journal Of Hospitality, Leisure, Sport \& Tourism Education. Volume 22. https://Www.Sciencedirect.Com/Science/ Article/Pii/S1473837616300995

2017. Redressing The Balance: Inverted Hierarchies In The Tourism Classroom. Journal of Hospitality, Leisure, Sport \& Tourism Education. Volume 21, Part B. https://Www.Sciencedirect.Com/Science/ Article/Pii/S1473837616300818 